\title{
The effects of feed intake and purified cellulose on the endogenous ileal amino acid flow in growing pigs
}

\author{
BY S. FURUYA* AND Y. KAJI \\ Department of Animal Production, Kyushu National Agricultural Experiment Station, Nishigoshi, \\ Kumamoto 861-11, Japan
}

(Received II December 1990-Accepted 19 September 1991)

\begin{abstract}
The effects of level of feed intake (0.8,1.2 and $1.6 \mathrm{~kg} / \mathrm{d})$ and body-weight of the pig (49 and $92 \mathrm{~kg}$ ) in Expt 1, and dietary neutral-detergent fibre (NDF; 30, 60, 90, 120 and $150 \mathrm{~g} / \mathrm{kg}$ ) in Expt 2 on the endogenous ileal flow of amino acids (AA) and nitrogen were studied with protein-free diets into which purified wood cellulose was incorporated at the expense of maize starch. In Expt 1, one of the proteinfree diets containing $90 \mathrm{~g} \mathrm{NDF} / \mathrm{kg}$ was used. Female pigs were fitted with a simple ' $\mathrm{T}$ ' cannula at the terminal ileum. In Expt 1, the endogenous ileal $A A$ and $N$ flow, expressed as $\mathrm{g} / \mathrm{kg}$ dry matter (DM) intake, decreased significantly $(P<0.05)$ with increasing DM intake, except for proline. By contrast, the values expressed as $\mathrm{g} / \mathrm{d}$ remained constant. There was no significant difference in endogenous ileal flow $(P>0.05)$ between initial body-weights of 45 and $90 \mathrm{~kg}$ except for histidide, isoleucine, phenylalanine, threonine, valine and serine, in which the ileal flow determined at the higher body-weight was significantly higher $(P<0.05)$. In Expt 2 , the effects of dietary cellulose levels on the endogenous ileal flow of $\mathrm{AA}$ and $\mathrm{N}$ were not significant $(P>0.05)$, although the values tended to increase as dietary cellulose levels increased for most $\mathbf{A A}$ and for $\mathbf{N}$. It is concluded that the daily endogenous ileal flow of $\mathrm{AA}$ and $\mathrm{N}$ remains relatively similar at different $\mathrm{DM}$ intake and cellulose levels. Therefore, correction of apparent ileal digestibility of $\mathrm{AA}$ and $\mathrm{N}$ to the true ileal digestibility should be made with the endogenous ileal flow values expressed on a daily amount basis, not the values expressed on a DM intake basis.
\end{abstract}

Amino acids: Endogenous ileal flow: Pig

The determination of true ileal amino acid (AA) digestibility is important to the improvement of feed formulation in pigs (Furuya \& Kaji, 1991). When determining true digestibility it is necessary to know the endogenous ileal AA flow. Dry matter (DM) intake is the most commonly used reference base for the endogenous ileal AA. This base assumes that the amounts of endogenous ileal AA are directly related to DM intake; but there have been no studies specifically designed to evaluate the influence of feed intake levels on endogenous ileal AA output and the basis for the endogenous connection is doubtful. Green et al. (1987) found a decrease in apparent ileal AA digestibility with decreasing feed intake and suggested that the endogenous flow remained relatively similar at different DM intakes. An increase in endogenous ileal AA flow with higher levels of fibre in the diets has been demonstrated (Sauer et al. 1977; Taverner et al. 1981). By contrast, Drake (1990) found no effect of increased dietary fibre intake on endogenous ileal $\mathrm{N}$ flow. Additionally, an increasing intake of indigestible DM apparently caused no increase in the losses of endogenous protein (Taverner et al. 1981). In order to clarify this controversy the present study was designed to determine the effects of feed (Expt 1) and cellulose (Expt 2) intakes on the ileal flow of endogenous AA and nitrogen in pigs.

* Present address: Department of Animal Production, Tohoku National Agricultural Experiment Station, Morioka 020-01, Japan. 
MATERIALS AND METHODS

Animals

In Expt 1, six 4-month-old female pigs (Hampshire $\times$ (Large White $\times$ Landrace)) weighing approximately $45 \mathrm{~kg}$ initially were used in a replicated $3 \times 3$ Latin square design, involving three feed intake levels and three periods. The same pigs were used again when they reached $90 \mathrm{~kg}$ ( 6 months old) in an experiment with the same design.

In Expt 2, a $5 \times 5$ Latin square design, involving five cellulose levels and five periods, was conducted with five 3-month-old female pigs (Hampshire $\times$ (Large White $\times$ Landrace), approximately $32 \mathrm{~kg}$ initially). All pigs in both experiments were fitted with a simple ' $\mathrm{T}$ ' cannula at the terminal ileum, approximately $300 \mathrm{~mm}$ anterior to the ileo-caecal junction. The cannula and surgical technique were identical to those described by Furuya et al. (1974). The pigs were housed and fed in individual concrete-floored pens with no bedding. The room temperature was not controlled. The experiment at $49 \mathrm{~kg}$ in Expt 1 and Expt 2 was conducted in the summer and experiment at $92 \mathrm{~kg}$ in Expt 1 was conducted in the autumn.

\section{Diets}

The composition of the diets used in Expts 1 and 2 is shown in Table 1. Purified wood cellulose was incorporated into diets, replacing maize starch, to provide five levels of neutral-detergent fibre (NDF) from 30 to $150 \mathrm{~g} / \mathrm{kg}$. Chromic oxide was added to each diet at a level of $1 \mathrm{~g} / \mathrm{kg}$ as an indigestible marker. The chemical composition of the diets is given in Table 1. Crude protein $(\mathrm{N} \times 6.25)$ and indispensable AA composition were determined on only the diet that contained $30 \mathrm{~g} \mathrm{NDF} / \mathrm{kg}$.

\section{Feeding regimen and sampling of ileal digesta}

In Expt 1, the protein-free diet with $90 \mathrm{~g} \mathrm{NDF} / \mathrm{kg}$ was fed at three levels, i.e. $0 \cdot 8,1 \cdot 2$ and $1.6 \mathrm{~kg} / \mathrm{d}$ (air-dry basis). In Expt 2, the pigs were given $1.2 \mathrm{~kg}$ protein-free diets $/ \mathrm{d}$ at five levels of cellulose intake in each period.

Each period of treatment with the diets lasted $4 \mathrm{~d}$. Equal amounts of feed were given every $8 \mathrm{~h}$ at $01.00,09.00$ and 17.00 hours each day. Water was supplied ad lib. Each treatment period started with the 17.00 hours feeding. Samples of ileal digesta were obtained on the 2 nd, 3 rd and 4 th days of treatment between 13.00 and 15.00 hours, i.e. starting $44 \mathrm{~h}$ after initiating treatments. Similar procedures were used previously (Furuya et al. 1986; Furuya \& Kaji, 1989).

For $3 \mathrm{~d}$ between each of the $4 \mathrm{~d}$ treatments, the pigs were given $1.2 \mathrm{~kg} / \mathrm{d}$ of a normal grower diet containing $160 \mathrm{~g}$ crude protein $/ \mathrm{kg}$. Again this feed was provided as three equal meals at $8 \mathrm{~h}$ intervals.

\section{Analytical and statistical procedures}

The analysis of N, DM and crude fibre in feed and ileal digesta were carried out according to the Association of Official Analytical Chemists (1975). Dietary NDF content was determined by the method of Van Soest \& Wine (1967) and $\mathrm{Cr}_{2} \mathrm{O}_{3}$ according to the method of Fenton \& Fenton (1979). The AA composition of acid-hydrolysates was determined using a Shimadzu (model LC-6A) AA analyser. Protein hydrolysis was carried out using $6 \mathrm{M}$-hydrochloric acid in sealed, evacuated tubes maintained at $110^{\circ}$ for $24 \mathrm{~h}$. Because of a poor resolution between the peaks on the chromatogram for tyrosine and some unknown substance(s), results of tyrosine have been excluded. Tryptophan and cystine were not determined and caution may be required in interpreting methionine data due to its possible underestimation because of oxidation during hydrolysis. 
Table 1. Composition $(\mathrm{g} / \mathrm{kg})$ of experimental diets*

\begin{tabular}{|c|c|c|c|c|c|}
\hline Dietary NDF level $(\mathrm{g} / \mathrm{kg}) \ldots$ & 30 & 60 & 90 & 120 & 150 \\
\hline \multicolumn{6}{|l|}{ Ingredients } \\
\hline Maize starch & 826.9 & 793.7 & $760 \cdot 6$ & $727 \cdot 4$ & $694 \cdot 3$ \\
\hline Purified cellulose & $33 \cdot 1$ & $66 \cdot 3$ & $99 \cdot 4$ & $132 \cdot 6$ & $165 \cdot 7$ \\
\hline Others $\ddagger$ & $140 \cdot 0$ & $140 \cdot 0$ & $140 \cdot 0$ & $140 \cdot 0$ & $140 \cdot 0$ \\
\hline \multicolumn{6}{|l|}{ Chemical composition } \\
\hline Dry matter & 856 & 857 & 854 & 860 & 865 \\
\hline Crude protein $\S(\mathrm{N} \times 6.25)$ & 3 & & & & \\
\hline Crude fibre $\|$ & 22 & 44 & 66 & 88 & 109 \\
\hline NDF & 30 & 60 & 90 & 120 & 150 \\
\hline \multicolumn{6}{|l|}{$\begin{array}{l}\text { Indispensable amino acid } \\
\text { composition }\end{array}$} \\
\hline Arginine & $0 \cdot 13$ & & & & \\
\hline Histidine & 0.07 & & & & \\
\hline Isoleucine & $0 \cdot 11$ & & & & \\
\hline Leucine & $0 \cdot 31$ & & & & \\
\hline Lysine & $0 \cdot 12$ & & & & \\
\hline Methionine & 0.06 & & & & \\
\hline Phenylalanine & $0 \cdot 14$ & & & & \\
\hline Threonine & 0.09 & & & & \\
\hline Valine & $0 \cdot 16$ & & & & \\
\hline
\end{tabular}

NDF, neutral-detergent fibre.

* Air-dry basis.

$\dagger \mathrm{KC}^{- \text {floc }}{ }^{\overline{\mathrm{n}}}$ (purified wood cellulose made from pulp, passed through a 100 mesh screen); Toyo Kokusaku Pulp Co., Ltd.

$\ddagger$ All diets also contained $(\mathrm{g} / \mathrm{kg})$ : dextrose 100 , tricalcium phosphate 20 , sodium chloride 5 , potassium carbonate 8 , magnesium sulphate 2 , vitamin and mineral mixtures 4 , chromic oxide 1 . Vitamin and mineral mixtures supplied the following quantities $(\mathrm{mg} / \mathrm{kg}$ diet): retinol $1 \cdot 3$, cholecalciferol $22 \mu \mathrm{g}, \alpha$-tocopherol 45 , thiamin 6 , riboflavin 14 , nicotinic acid 36, pyridoxine 6 , pantothenic acid 42 , biotin $2 \mu \mathrm{g}$, cyanocobalamin $20 \mu \mathrm{g}$, pteroylmonoglutamic acid $4 \cdot 8$, choline 690 , zinc 96 , iron 80 , manganese 80 , copper 16 , iodine 1.6 .

$\S$ Crude protein and amino acid composition were determined only for dietary NDF level of $30 \mathrm{~g} / \mathrm{kg}$.

$\|$ Calculated from the chemical analyses of the purified cellulose.

The data were analysed by analysis of variance. In Expt 1, feeding level and body-weight effects were tested as well as a feeding level $\times$ body-weight interaction. An adjustment for unequal numbers was made by the method of Snedecor \& Cochran (1967). The values obtained at the different levels of feeding or cellulose were subjected to simple linear regression analysis.

\section{Calculation of endogenous ileal flow of $A A$ and $N$}

The flows of AA and $\mathrm{N}$ through the terminal ileum were calculated using $\mathrm{Cr}_{2} \mathrm{O}_{3}$ in the diet: $\mathrm{Cr}_{2} \mathrm{O}_{3}$ in the ileal digesta values according to the following equation:

$$
\left(\begin{array}{c}
\text { ileal flow of AA } \\
\text { or } \mathrm{N}(\mathrm{g} / \mathrm{d})
\end{array}\right)=\left(\begin{array}{c}
\text { ileal AA or } \\
\mathrm{N}(\mathrm{g} / \mathrm{g})
\end{array}\right) \times\left(\frac{\text { diet } \mathrm{Cr}_{2} \mathrm{O}_{3}(\mathrm{~g} / \mathrm{g})}{\text { ileal } \mathrm{Cr}_{2} \mathrm{O}_{3}(\mathrm{~g} / \mathrm{g})}\right) \times\left(\begin{array}{c}
\text { feed } \\
\text { intake }(\mathrm{g} / \mathrm{d})
\end{array}\right)
$$

\section{RESULTS}

Endogenous ileal AA output expressed on a daily basis

A protein-free diet contained $3 \mathrm{~g}$ crude protein $/ \mathrm{kg}$ as shown in Table 1 , but the calculated ileal $A A$ and $N$ flows were defined as the endogenous ileal flow on a protein-free diet. The endogenous ileal AA and $\mathrm{N}$ flows in Expt 1 are shown in Tables 2 and 3. The values for one pig (given $1.2 \mathrm{~kg} / \mathrm{d}$ at $92 \mathrm{~kg}$ ) were discarded as the $\mathrm{AA}: \mathrm{Cr}_{2} \mathrm{O}_{3}$ and $\mathrm{N}: \mathrm{Cr}_{2} \mathrm{O}_{3}$ ratios of 


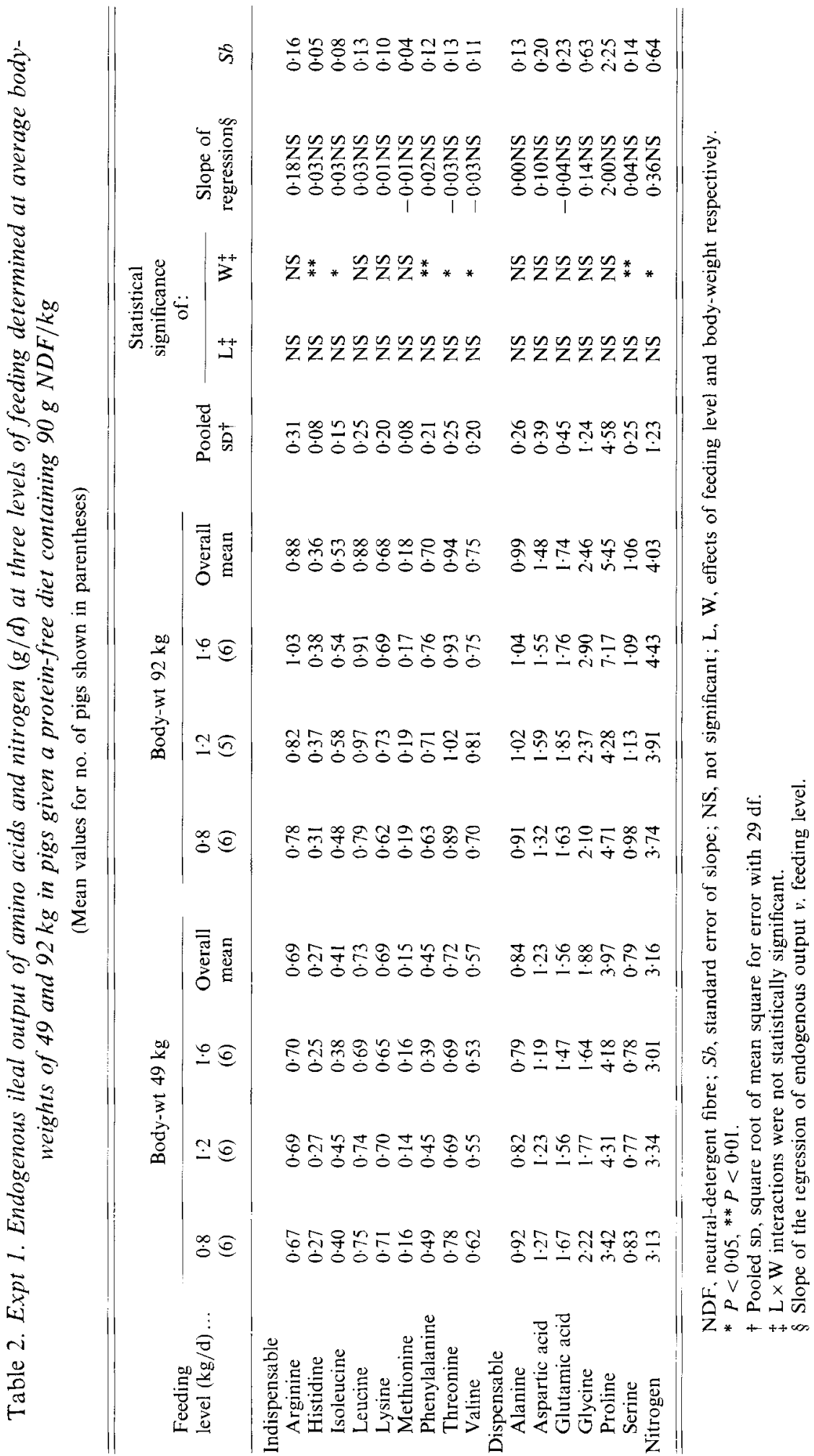




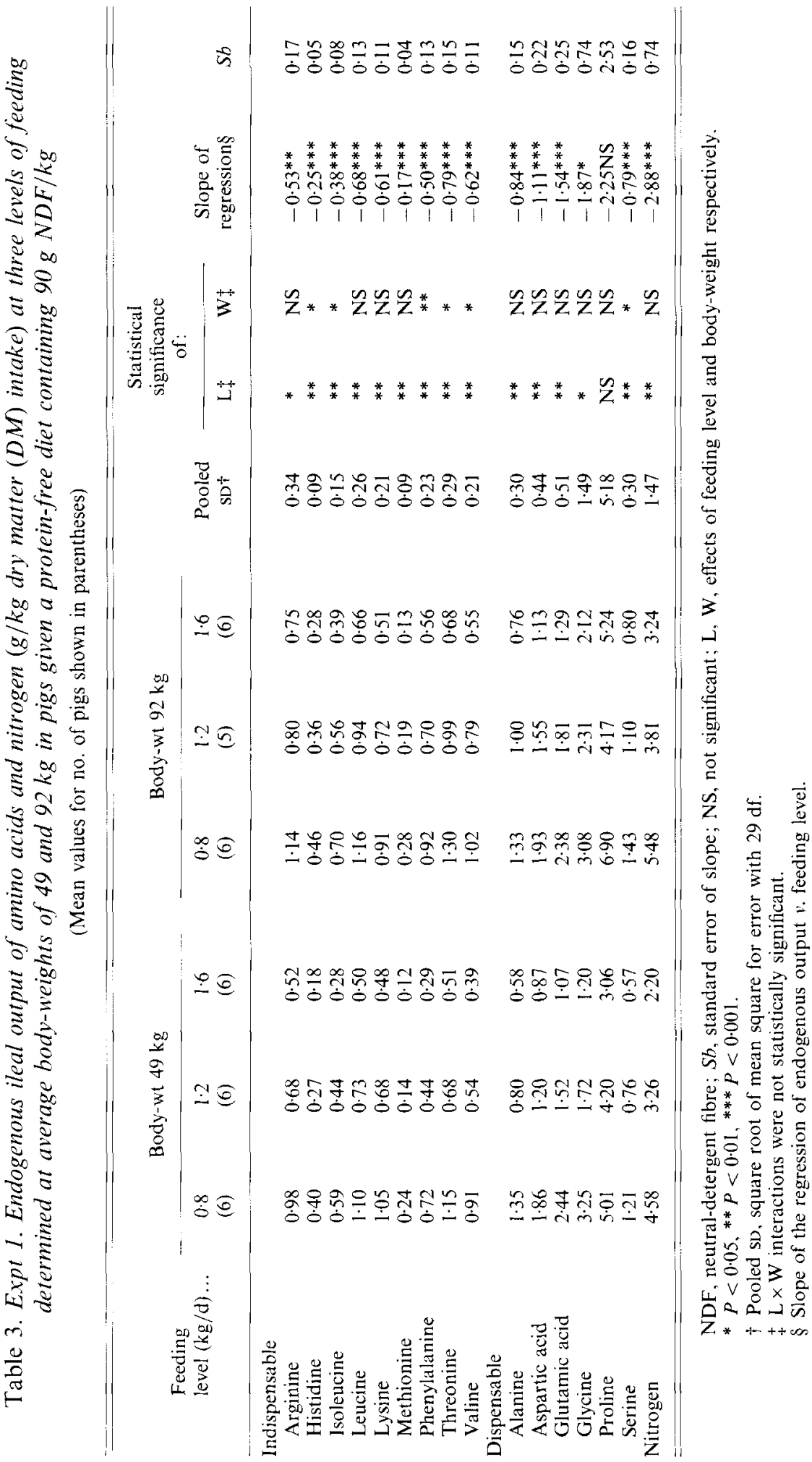


Table 4. Expt 2. Endogenous ileal output of amino acids and nitrogen $(\mathrm{g} / \mathrm{d})$ in pigs given protein-free diets with different dietary NDF levels

(Mean values with their standard errors for five pigs)

\begin{tabular}{|c|c|c|c|c|c|c|c|c|}
\hline $\begin{array}{l}\text { NDF level in } \\
\text { diet }(\mathrm{g} / \mathrm{kg}) \ldots\end{array}$ & 30 & 60 & 90 & 120 & 150 & SEM & $\begin{array}{l}\text { Slope of } \\
\text { regression* } \\
\left(\times 10^{-3}\right)\end{array}$ & $\begin{array}{c}S b \\
\left(\times 10^{-3}\right)\end{array}$ \\
\hline \multicolumn{9}{|l|}{ Indispensable } \\
\hline Arginine & 0.70 & 0.74 & 0.82 & 0.77 & 0.67 & 0.17 & $-0 \cdot 12 \mathrm{NS}$ & $1 \cdot 64$ \\
\hline Histidine & 0.29 & $0 \cdot 26$ & $0 \cdot 30$ & $0 \cdot 30$ & 0.32 & 0.04 & $0 \cdot 35 \mathrm{NS}$ & $0 \cdot 38$ \\
\hline Isoleucine & 0.40 & $0 \cdot 36$ & 0.42 & 0.41 & $0 \cdot 46$ & 0.05 & $0.58 \mathrm{NS}$ & 0.55 \\
\hline Leucine & 0.69 & 0.61 & $0 \cdot 72$ & 0.73 & $0-80$ & $0 \cdot 10$ & $1 \cdot 12 \mathrm{NS}$ & 1.00 \\
\hline Lysine & 0.53 & 0.49 & 0.56 & 0.56 & 0.62 & 0.06 & $0.81 \mathrm{NS}$ & 0.64 \\
\hline Methionine & $0 \cdot 14$ & $0 \cdot 13$ & $0 \cdot 14$ & $0 \cdot 14$ & $0 \cdot 16$ & 0.02 & $0 \cdot 14 \mathrm{NS}$ & $0 \cdot 20$ \\
\hline Phenylalanine & 0.52 & 0.51 & 0.59 & 0.56 & 0.64 & 0.09 & $0.94 \mathrm{NS}$ & 0.85 \\
\hline Threonine & 0.63 & 0.57 & 0.69 & 0.69 & 0.76 & $0 \cdot 10$ & $1 \cdot 26 \mathrm{NS}$ & 1.00 \\
\hline Valine & 0.55 & $0 \cdot 50$ & 0.60 & 0.60 & $0-66$ & 0.08 & $1.01 \mathrm{NS}$ & $0 \cdot 81$ \\
\hline \multicolumn{9}{|l|}{ Dispensable } \\
\hline Alanine & 0.78 & 0.70 & 0.81 & 0.77 & 0.77 & 0.11 & $0.18 \mathrm{NS}$ & 1.09 \\
\hline Aspartic acid & $1 \cdot 12$ & 1.06 & $1 \cdot 16$ & $1 \cdot 15$ & $1 \cdot 16$ & 0.15 & $0.60 \mathrm{NS}$ & 1.53 \\
\hline Glutamic acid & 1.39 & 1.23 & 1.42 & 1.41 & 1.45 & $0 \cdot 16$ & $0.96 \mathrm{NS}$ & $1 \cdot 64$ \\
\hline Glycine & 1.73 & 1.87 & $2 \cdot 78$ & $2 \cdot 12$ & $1 \cdot 70$ & 0.57 & $0.63 \mathrm{NS}$ & 5.92 \\
\hline Proline & $4 \cdot 31$ & 3.66 & $5 \cdot 44$ & 5.15 & $2 \cdot 80$ & 1.52 & $-5 \cdot 16 \mathrm{NS}$ & $15 \cdot 66$ \\
\hline Serine & 0.77 & 0.69 & 0.83 & 0.81 & 0.83 & 0.12 & $0.80 \mathrm{NS}$ & $1 \cdot 16$ \\
\hline Nitrogen & $2 \cdot 97$ & $2 \cdot 79$ & 3.67 & $3 \cdot 44$ & $2-82$ & 0.50 & $1 \cdot 19 \mathrm{NS}$ & $5 \cdot 19$ \\
\hline
\end{tabular}

NDF, neutral-detergent fibre; $S b$, standard error of slope; NS, not significant.

* Slope of the regression of endogenous output $v . \mathrm{NDF}$ level.

the ileal digesta sample were inordinately high (approximately twice the value of other pigs on the same level of feeding).

The endogenous ileal AA and $\mathrm{N}$ flows, expressed as $\mathrm{g} / \mathrm{d}$, were not affected $(P>0.05)$ by the level of intake of protein-free diet (Table 2). None of the regressions relating endogenous flow to feeding level was significantly different from zero at each body-weight, although for some AA there was a tendency for a decrease in endogenous flow with increasing feeding levels at the lower body-weight and an increase at the higher bodyweight, this being marked for glycine and alanine.

Comparison between the rates of endogenous flow at 49 and $92 \mathrm{~kg}$ indicated no significant differences for arginine, leucine, lysine, methionine, alanine, aspartic acid, glutamic acid, glycine and proline. However, for histidine, isoleucine, phenylalanine, threonine, valine, serine and $\mathrm{N}$, the daily output determined at $92 \mathrm{~kg}$ was significantly higher $(P<0.05)$ than that at $49 \mathrm{~kg}$.

\section{Endogenous ileal AA output expressed on a DM intake basis}

The endogenous ileal AA and $\mathrm{N}$ outputs, expressed as $\mathrm{g} / \mathrm{kg} \mathrm{DM}$ intake, are shown in Table 3. On this basis endogenous ileal $\mathrm{N}$ and $\mathrm{AA}$ flows decreased with the increasing feed intake. The slopes of the regression equations relating endogenous output to feeding level were significantly different $(P<0.05)$ from zero, for $\mathrm{N}$ and for all AA except for proline.

\section{Effect of cellulose levels in the diets}

As shown in Table 4, the endogenous ileal AA and N flows were not affected by cellulose intake, although for most AA and for $\mathrm{N}$ values tended to increase as dietary NDF levels increased. The regressions were positive for all $\mathrm{AA}$ and for $\mathrm{N}$ except those for arginine and 
proline which were negative; however, they were not significant. Proline and glycine were the most prominent dispensable AA of the endogenous ileal AA, while arginine, leucine and threonine were the most prominent indispensable AA.

\section{DISCUSSION}

On the assumption that the endogenous flow is divided into two fractions, one a constant fraction and one which varies directly with DM intake, the relationship between the endogenous ileal flow $(\mathrm{EI} ; \mathrm{g} / \mathrm{d})$ and DM intake can be expressed as follows:

$$
\mathrm{EI}=a+b \times \mathrm{DM} \text { intake }(\mathrm{kg} / \mathrm{d}) \text {, }
$$

in which $a$ is the constant and $b$ is the slope of this equation. The endogenous flow per unit DM intake can be calculated as follows:

$$
\mathrm{EI}(\mathrm{g} / \mathrm{kg} \mathrm{DM} \text { intake })=\frac{a}{\mathrm{DM} \text { intake }(\mathrm{kg} / \mathrm{d})}+b
$$

Since in the present study the slopes of the regression equations were not significantly different from zero for all AA and for $\mathrm{N}$ (Table 2), the slope constant $b$ can be neglected. Thus, for lysine, for example, the relationship between the endogenous ileal flow $(y ; \mathrm{g} / \mathrm{kg}$ DM intake) and DM intake $(x ; \mathrm{kg} / \mathrm{d})$ is expressed by $y=0.68 / x$, in which the constant $a$, 0.68 , represents the average endogenous lysine flow $(\mathrm{g} / \mathrm{d})$ determined at the two bodyweights (Table 2). The values for lysine obtained in Expt 1 (Table 3) v. DM intake are shown in Fig. 1.

The present observations explain an increase in the apparent ileal AA digestibility with increased DM intake (Haydon et al. 1984; Green et al. 1987). Although Sauer et al. (1982) found that the apparent ileal digestibility of AA was largely unaffected by DM intake, a high level of crude protein, $194 \mathrm{~g} / \mathrm{kg}$ DM, was used in their experiment; therefore, such effects would have been difficult to detect, as suggested by Green et al. (1987).

Several workers (Sauer et al. 1977; Taverner et al. 1981) have reported an increase in the endogenous ileal AA output per unit DM intake with increasing dietary fibre. However, in the present study with wood cellulose (Expt 2) this effect was not found to be significant. A similar lack of effect was also found by de Lange et al. (1989a) and Drake (1990). In the study of Sauer et al. (1977), with pigs fed on protein-free diets containing increasing levels of cellulose $(50,100$ or $150 \mathrm{~g} / \mathrm{kg})$, it was found that the total ileal AA flow was $10.95,13.79$ and $14.13 \mathrm{~g} / \mathrm{kg}$ DM intake. However, the increase in dietary cellulose was associated with a decline in voluntary food intake and if the values are expressed as daily flows the total ileal AA flows at different levels of cellulose were not significantly different: 17.0, 18.7 and $15 \cdot 7 \mathrm{~g} / \mathrm{d}$ with cellulose inclusions of 50,100 and $150 \mathrm{~g} / \mathrm{kg}$ respectively (Sauer et al. 1977). Taverner et al. (1981) observed significantly greater $(P<0 \cdot 05)$ endogenous ileal losses with pigs given a protein-free diet containing $50 \mathrm{~g}$ cellulose $/ \mathrm{kg}$ than with no added cellulose, and slight increases in the endogenous ileal flow when dietary NDF level was increased further to approximately 50,140 and $190 \mathrm{~g} / \mathrm{kg}$; the magnitudes of the increases were generally similar to those observed with dietary NDF levels ranging from 30 to $150 \mathrm{~g} / \mathrm{kg}$ in the present study (Table 4). Furthermore, Taverner et al. (1981) reported that an increase in the amount of indigestible DM passing through the ileum caused no apparent increase in endogenous protein losses. From the findings of the present study and other studies (Sauer et al. 1977; Taverner et al. 1981; de Lange et al. 1989 a; Drake, 1990), it may be concluded that cellulose levels do not greatly affect the endogenous ileal AA flow except when the cellulose levels are very low. 


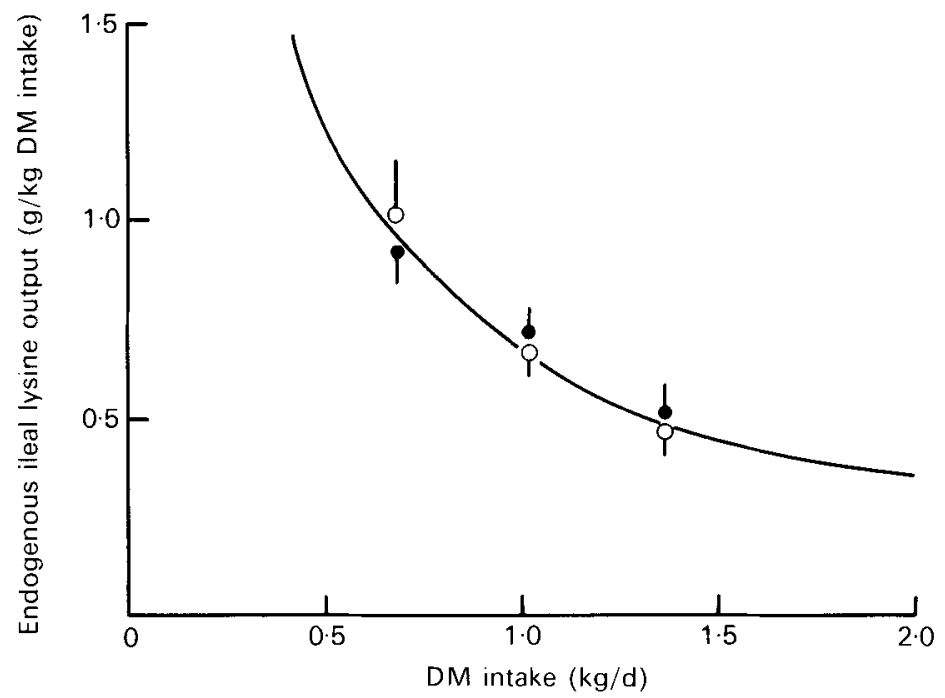

Fig. 1. Expt 1. Effect of dry matter $(\mathrm{DM})$ intake $(\mathrm{kg} / \mathrm{d} ; x)$ on endogenous iled lysine output $(\mathrm{g} / \mathrm{kg} \mathrm{DM}$ intake: $y)$ in pigs; $y=0.68 / x$, in which the constant value represents the average endogenous ileal lysine output $(\mathrm{g} / \mathrm{d})$ obtained at both average body-weights (for details see Table 2). Values are means with their standard errors represented by vertical bars for five or six pigs, determined at $49 \mathrm{~kg}(\mathrm{O})$ and $92 \mathrm{~kg}(\boldsymbol{O})$. For details of diets, see Table 1.

The findings of the present study lead to the conclusion that the daily endogenous ileal flow of AA and $\mathrm{N}$ remains relatively similar at different DM intake and cellulose levels. This conclusion contrasts with that of Mitchell (1924) who reported on faecal rather than ileal $\mathrm{N}$ losses from rats, finding this varied with both feed intake and the fibre content of the diet. A similar finding has also been reported for pigs (Schneider, 1935; Whiting \& Bezeau, 1957). The increase in the endogenous faecal $N$ output with DM intake and dietary fibre level is probably a result of the action of the microflora in the large intestine, since a large proportion of faecal $\mathrm{N}$ from pigs is of bacterial origin (Mason et al. 1976). The rate of fermentation and, hence, bacterial protein in faeces can be increased by the additional substrate provided on increasing DM intake, more specifically indigestible DM intake, as suggested by Taverner et al. (1981) and Low (1982). Again compared with endogenous faecal $\mathrm{N}$, endogenous ileal flow of AA and $\mathrm{N}$ is suggested to be little influenced, if at all, by the action of the microflora (Mason et al. 1976; Laplace et al. 1989).

The endogenous ileal AA flow values have been determined by giving a protein-free diet (Holmes et al. 1974; Sauer et al. 1977; Taverner et al. 1981; de Lange et al. 1989 a, b; Wang $\&$ Fuller, 1989) or by regression to zero AA intake using a series of diets containing graded levels of the test source of protein (Taverner et al. 1981; Leibholz, 1982; Furuya \& Kaji, 1989), and the two methods have given similar estimates (Taverner et al. 1981; Leibholz, 1982; Kies et al. 1986; Furuya \& Kaji, 1989). In the present study, the endogenous ileal flow values of $\mathrm{AA}$ and $\mathrm{N}$ were determined using protein-free diets. However, the protein-free method is open to some criticism (Sauer et al. 1977; Low, 1982). Sauer et al. (1977) found true digestibility values exceeding 1.00 for proline and glycine due to their overestimated endogenous values. Furthermore, they suggested that endogenous estimates of all other AA were probably also overestimated. However, the results of a regression method by Taverner et al. (1981) suggested that proline and glycine might be exceptional. Recently, de Lange et al. $(1989 \mathrm{~b})$ reported that the recovery of endogenous protein in ileal digesta was lower when AA were administered intravenously and that a major part of this difference was due 
to a decrease in the recovery of proline and glycine in the ileum. Therefore, it may be concluded that the endogenous ileal AA flow estimated by giving a protein-free diet or by regression analysis can be used to calculate the true ileal digestibility for at least the indispensable AA.

Another problem in the determination of the endogenous ileal AA flow is related to the body-weight of the pig. In the present study the endogenous ileal flow values were shown to vary slightly with body-weight changes, although a significant increase $(P<0.05)$ was observed with increasing body-weight for some AA (Table 2). Armstrong \& Mitchell (1955) showed no significant change in faecal $\mathrm{N}$ output from a protein-free diet with increasing body-weight in pigs. However, an increase in the endogenous ileal $\mathrm{N}$ output with increasing body-weight was observed by Drake (1990), indicating that a heavier animal will have a higher $\mathrm{N}$ secretion. Green et al. (1987) fed pigs on two protein-free diets of different cellulose levels at a different body-weight for each diet and suggested that the observed increase in the endogenous ileal AA flow might be due to the dietary fibre levels, but the body-weight changes could also be an explanation for the increase.

In Expt 1 two different ages of the pigs were studied at a different body-weight, and the observed increase in the endogenous flow might be due to the effect of age, although no obvious fact to prove the suggestion has been obtained. Therefore, further studies on endogenous ileal $\mathrm{N}$ and $\mathrm{AA}$ flow relative to body-weight and age of pigs may be required.

The authors thank Y. Shigaki, F. Hayashi, H. Hashimoto and J. Shimasaki for their skilled surgical assistance and care of the animals. They are also grateful to Y. Hatori for AA analysis and M. Yagi, T. C. Wang and M. F. Fuller for reviewing the manuscript.

\section{REFEREN CES}

Armstrong, D. G. \& Mitchell, H. H. (1955). Protein nutrition and the utilization of dietary protein at different levels of intake by growing swine. Journal of Animal Science 14, 49-68.

Association of Official Analytical Chemists (1975). Official Methods of Analysis, 12th ed. Washington, DC: Association of Official Analytical Chemists.

de Lange, C. F. M., Sauer, W. C., Mosenthin, R. \& Souffrant, W. B. (1989a). The effect of feeding different protein-free diets on the recovery and amino acid composition of endogenous protein collected from the distal ileum and feces in pigs. Journal of Animal Science 67, 746-754.

de Lange, C. F. M., Sauer, W. C. \& Souffrant, W. B. (1989 b). The effect of protein status of the pig on the recovery and amino acid composition of endogenous protein in digesta collected from the distal ileum. Journal of Animal Science 67, 755-762.

Drake, A. P. (1990). The development of an in vitro system for predicting nutrient digestibility in feeds for pigs. PhD Thesis, University of Aberdeen.

Fenton, T. W. \& Fenton, M. (1979). An improved procedure for the determination of chromic oxide in feed and feces. Canadian Journal of Animal Science 59, 631-634.

Furuya, S. \& Kaji, Y. (1989). Estimation of the true ileal digestibility of amino acids and nitrogen from their apparent values for growing pigs. Animal Feed Science and Technology 26, 271-285.

Furuya, S. \& Kaji, Y. (1991). Additivity of the apparent and true ileal digestible amino acid supply in barley, maize, wheat or soya-bean meal based diets for growing pigs. Animal Feed Science and Technology 32, 321-331.

Furuya, S., Nagano, R. \& Kaji, Y. (1986). True ileal digestibility of crude protein and amino acids in protein sources as determined by a regression method for growing pigs. Japanese Journal of Zootechnical Science $\mathbf{5 7}$, $857-870$.

Furuya, S., Takahashi, S. \& Omori, S. (1974). The establishment of T-piece cannula fistulas into the smail intestine of the pig. Japanese Journal of Zootechnical Science 45, 42-44.

Green, S., Bertrand, S. L.. Duron, M. J. C. \& Maillard, R. A. (1987). Digestibility of amino acids in maize, wheat and barley meal, measured in pigs with ileo-rectal anastomosis and isolation of the large intestine. Journal of Science of Food and Agriculture 41, 2943.

Haydon, K. D., Knabe, D. A. \& Tanksley, T. D. Jr (1984). Effects of level of feed intake on nitrogen, amino acid and energy digestibilities measured at the end of the small intestine and over the total digestive tract of growing pigs. Journal of Animal Science 57, $717 \cdot 724$.

Holmes, J. H., Bayley, H. S., Leadbeater, P. A. \& Horney, F. D. (1974). Digestion of protein in small and large intestine of the pig. British Journal of Nutrition 32, 479 489. 
Kies, A. K., Moughan, P. J. \& Smith, W. C. (1986). The apparent and true ileal digestibility of nitrogen and amino acids in lactic casein for the growing pig. Animal Feed Science and Technology 16, 169-178.

Laplace, J. P., Darcy-Vrillon, B., Pérez, J. M., Henry, Y., Giger, S. \& Sauvant, D. (1989). Associative effects between two fibre sources on ileal and overall digestibilities of amino acids, energy and cell-wall components in growing pigs. British Journal of Nutrition 61, 75-87.

Leibholz, J. (1982). The flow of endogenous nitrogen in the digestive tract of young pigs. British Journal of Nutrition 48,509-517.

Low, A. G. (1982). Digestibility and availability of amino acids from feedstuffs for pigs: a review, Livestock Production Science 9, 51 1-520.

Mason, V. C., Just, A. \& Bech-Anderson, S. (1976). Bacterial activity in the hind-gut of pigs. 2. Its influence on the apparent digestibility of nitrogen and amino acids. Zeitschrift fur Tierphysiologie, Tierernahrung und Futtermittelkunde 36, 310-324.

Mitchell, H. H. (1924). A method of determining the biological value of protein. Journal of Biological Chemistry 58, 873-903.

Sauer, W. C., Just, A. \& Jorgensen, H. (1982). The influence of daily feed intake on the apparent digestibility of crude protein, amino acids, calcium and phosphorus at the terminal ileum and overall in pigs. Zeitschrift fur Tierphysiologie, Tierernahrung und Futtermittelkunde 48, 177-182.

Sauer, W. C., Stothers, S. C. \& Parker, R. J. (1977). Apparent and true availabilities of amino acids in wheat and milling by-products for growing pigs. Canadian Journal of Animal Science 57, 775-784.

Schneider, B. H. (1935). The subdivision of the metabolic nitrogen in the feces of the rat, swine, and man. Journal of Biological Chemistry 109, 249-278.

Snedecor, G. W. \& Cochran, W. G. (1967). Statistical Methods, 6th ed. Ames, Iowa: Iowa State University Press.

Taverner, M. R., Hume, I. D. \& Farrell, D. J. (1981). Availability to pigs of amino acids in cereal grains. (1) Endogenous levels of amino acids in ileal digesta and faeces of pigs given cereal diets. British Journal of Nutrition 46, 149-158.

Van Soest, P. T. \& Wine, R. H. (1967). Use of detergents in analysis of fibrous feeds. (4) Determination of plant cell wall constituents. Journal of the Association of Official Analytical Chemists $\mathbf{5 0}, 50-55$.

Wang, T. C. \& Fuller, M. F. (1989). The optimum dietary amino acid pattern for growing pigs. 1. Experiments by amino acid deletion. British Journal of Nutrition $62,77-89$.

Whiting, F. \& Bezeau, L. M. (1957). The metabolic fecal nitrogen excretion of the pig as influenced by the amount of fibre in the ration and by body weight. Canadian Journal of Animal Science 37, 95-105. 